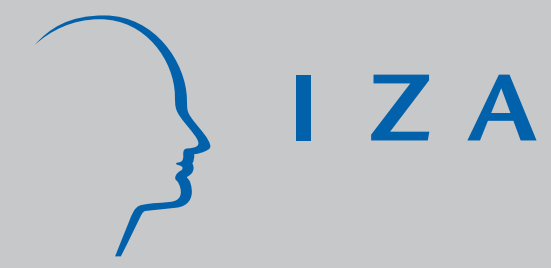

IZA DP No. 9992

How Successful Are Banking Sector Reforms in Emerging Market Economies? Evidence from Impact of Monetary Policy on Levels and Structures of Firm Debt in India

Sumon Kumar Bhaumik

Ali M. Kutan

Sudipa Majumdar

June 2016 


\title{
How Successful Are Banking Sector Reforms in Emerging Market Economies? Evidence from Impact of Monetary Policy on Levels and Structures of Firm Debt in India
}

\author{
Sumon Kumar Bhaumik \\ University of Sheffield and IZA \\ Ali M. Kutan \\ Southern Illinois University Edwardsville
}

Sudipa Majumdar

Middlesex University

Discussion Paper No. 9992

June 2016

IZA

P.O. Box 7240

53072 Bonn

Germany

Phone: +49-228-3894-0

Fax: +49-228-3894-180

E-mail: iza@iza.org

\begin{abstract}
Any opinions expressed here are those of the author(s) and not those of IZA. Research published in this series may include views on policy, but the institute itself takes no institutional policy positions. The IZA research network is committed to the IZA Guiding Principles of Research Integrity.

The Institute for the Study of Labor (IZA) in Bonn is a local and virtual international research center and a place of communication between science, politics and business. IZA is an independent nonprofit organization supported by Deutsche Post Foundation. The center is associated with the University of Bonn and offers a stimulating research environment through its international network, workshops and conferences, data service, project support, research visits and doctoral program. IZA engages in (i) original and internationally competitive research in all fields of labor economics, (ii) development of policy concepts, and (iii) dissemination of research results and concepts to the interested public.
\end{abstract}

IZA Discussion Papers often represent preliminary work and are circulated to encourage discussion. Citation of such a paper should account for its provisional character. A revised version may be available directly from the author. 


\section{ABSTRACT \\ How Successful Are Banking Sector Reforms in Emerging Market Economies? Evidence from Impact of Monetary Policy on Levels and Structures of Firm Debt in India*}

Many emerging markets have undertaken significant financial sector reforms especially in their banking sectors that have been quite critical for both financial development and real economic activity. In this paper, we investigate the success of banking reforms in India where significant banking reforms have been introduced since 1990s. Using the argument that wellfunctioning credit markets would reflect a bank channel for monetary policy at work, we test whether a change in monetary policy has predictable impact on borrowing behaviour of several types of firms, including business group affiliated, unaffiliated private firms, stateowned firms and foreign firms. The empirical results suggest that unaffiliated private firms have the most vulnerable to monetary policy stance during tight policy regimes. We also find that during tight monetary policy regimes, smaller firms are much more affected by monetary policy than large firms. In an easy money regime, monetary policy and the associated change in interest rate does not affect change in bank credit, change in total debt and the proportion of bank credit in total debt for any of the firms. We discuss the policy implications of the findings.

JEL Classification: $\quad$ E52, G21, G28, G32, O16

Keywords: $\quad$ banking reforms, monetary policy, credit markets, bank debt, debt structure

Corresponding author:

Sumon Kumar Bhaumik

Sheffield University Management School

University of Sheffield

Conduit Road

Sheffield S10 1FL

United Kingdom

E-mail: s.k.bhaumik@sheffield.ac.uk 


\section{Introduction}

The correlation - some would argue causal relation - between financial development and economic growth is well established, albeit with some caveats (King and Levine, 1993; Demetriades and Hussein, 1996; Arestis and Demetriades, 1997). Not surprisingly, over the past three decades, a large number of developing countries (including their fast-growth subset, emerging market economies) have undertaken reforms of their financial sector. While some of these reforms have been aimed at reducing transactions cost and improving informational efficiency of equity markets (Lagoarde-Segot, 2009), much of the reforms were aimed at the banking sectors of these countries that have been the central pillars of their financial systems for decades (Abiad, Detragiache and Tressel, 2010; Ağca and Celasun, 2012). At the same time, for a variety of reasons, corporate bond markets have remained underdeveloped in all but a handful - Brazil, China and Malaysia - of emerging market economies (Tendulkar, 2015).

The reforms aimed at the banking sector, in particular, aimed at reducing or eliminating the constraints imposed on banks by policies such as interest rate controls, directed credit and pre-emption of savings by the government that are generally associated with financial repression (Fry, 1997). Simultaneously, banks were accorded greater responsibility with respect to management of credit risk, by way of prudential norms involving recognition of loan losses and maintenance of adequate risk capital. Incumbent banks were also subjected to greater competition by way of liberalisation of the rules and regulations about entry of new foreign and domestic banks. The details of these changes to the banking landscape in emerging market economies have been discussed widely in the literature, in the context of countries such as China (Lardy, 2008), India (Bhaumik and Dimova, 2004; Bhaumik and Piesse, 2008), South Korea (Amsden and Euh, 1993), former communist economies of Soviet Union (Love and Rachinsky, 2015; Cojocaru et al, 2016) and Turkey (Akyuz, 1990). 
However, the economic reforms directed at the financial sectors of emerging market economies were often not complete, and significant market frictions remained. To begin with, the informational cost in these countries remained high, as the corporate landscape continued to be dominated by firms that had opaque ownership structures and entrenched management (Khanna and Palepu, 2000; Claessens and Fan, 2003). The cost of contract enforcement remained high as well, and in some cases the problem was further aggravated by weak or inadequate bankruptcy laws (Kang and Nayar, 2004). These characteristics of the credit market favoured incumbent firms that have proven track record and banking relationships (Banerjee, Cole and Duflo, 2004), those are able to post collateral or implicit and explicit guarantees of established firms within business networks (Fisman and Wang, 2010), and political connections (Khwaja and Mian, 2005; Tsai, Wang, Ho and Lin, 2016; Zhang, Su, Sun, Zhang and Shen, 2015). While this does not mean that banks in these countries do not employ commercial judgement about credit allocation (Firth et al., 2009), and the credit market frictions that favour incumbents and organisations such as business groups can be ameliorated over time (Bhaumik, Das and Kumbhakar, 2012). However, not enough is understood about the functioning of credit (more broadly, financial) markets as the different aspects of the reforms packages pull the market participants in different directions.

In this paper, we draw implications about the success of banking sector reforms in emerging market economies using the prism of monetary policy transmission in these economies. For our empirical analysis, we choose the context of India where there was significant and well documented progress in banking sector reforms from the early to the late nineties. Our results suggest that unaffiliated private firms have the most vulnerable to monetary policy stance during tight policy regimes where other types of firms are relatively less affected by changes in monetary policy. We also find that during tight monetary policy regimes, smaller firms are much more affected by monetary policy than large firms. Our results 
suggest that information costs and agency issues that were highlighted by extant research (e.g., Banerjee, Cole and Duflo, 2004) have not been completely ameliorated by banking sector reforms. They also have implications for complementary issues such as low cost bankruptcy proceedings and creditors' rights that are only now being addressed by the government. Our results, therefore, have implications for emerging market economies that embark on banking sector reforms.

The rest of the paper is structured as follows: Our empirical strategy is discussed in Section 2. In Section 3, we discuss the data and the summary statistics. The regression results and their implications are discussed in Section 4. Section 5 concludes.

\section{Empirical strategy}

Our empirical strategy is based on the argument that if credit markets work well then the bank channel for monetary policy would work as well, such that a change in monetary policy should have predictable impact on the borrowing patterns of firms. Specifically, a tightening of monetary policy should result in a reduction in the volume of total debt on the balance sheet of an average firm (Bernanke and Gertler, 1995; Oliner and Rudebusch, 1996). Further, this is more likely to be the case during tight money regimes than during easy money regimes (Bhaumik, Dang and Kutan, 2011), where the easiness or tightness of a monetary regime is indicated by an indicator such as the monetary condition index (Osborne-Kinch and Holton, 2010). The impact is likely to be greater for smaller and younger firms that are often less informationally transparent than their larger counterparts (Berger and Udell, 1998, 2006). Finally, as the cost of bank finance rises in the event of monetary tightening, relative to cost of capital from other sources, there should be an impact of a firm's debt structure, as captured by the ratio of bank debt to total debt (Huang, 2003). 
However, these general propositions would have to be refined for developing country and emerging market contexts. For example, given that firms in these countries are largely dependent on bank capital and have significantly underdeveloped bond markets (Bose and Coondoo, 2003), the impact of monetary policy on a firm's debt structure may be weak or insignificant. Similarly, the impact of monetary policy on bank loan itself is likely to be much more significant for firms that are unaffiliated to governments and organisational structures such as business groups. For state-owned firms (and those with strong relations with the state) may have preferential access to loans in these economies, especially where the banking sector is dominated by state-owned banks. By the same token, business group affiliated firms are likely to benefit from the existence of internal capital markets that can ameliorate the impact of monetary policy changes.

In other words, in developing economy and emerging market contexts, it would be prudent to focus on the impact of monetary policy on these unaffiliated firms, and contrast this impact with the impact of monetary policy on business group affiliated and state-owned firms. If banking sector reforms result in a level playing field and reduction in frictions in the credit market then there should be no observable difference between the impact of monetary policy on growth in bank credit and debt structure of unaffiliated firms and those of the firms in the aforementioned comparator groups. Continued presence of frictions, on the other hand, would result in greater impact of monetary policy on unaffiliated firms than on business group affiliated and state-owned firms. Similarly, following Berger and Udell (1998, 2006), and accounting for a host of factors such as absence of credit registers, weak bankruptcy laws and weak credit protection, in general, we should expect monetary policy to have a greater impact on smaller (younger) firms than on larger (older) firms. Following Bhaumik, Dang and Kutan (2011), this impact is likely to be greater during periods of tight monetary policy than during periods of easy monetary policy. 
In order to operationalise the empirical framework, following Huang (2003), we estimate the following regression models:

$$
\begin{aligned}
& B D_{i, t}=\alpha_{0}+\alpha_{1} B D_{i, t-1}+\alpha_{2} \Delta F_{t} T+\alpha_{3} \Delta F_{t}(1-T)+\Omega^{\prime} X+\mu_{t}+\vartheta_{i}+\epsilon_{i, t} \\
& \Delta B_{i, t}=\gamma_{0}+\gamma_{1} \Delta B_{i, t-1}+\gamma_{2} \Delta F_{t} T+\gamma_{3} \Delta F_{t}(1-T)+\Psi^{\prime} X+\mu_{t}+\vartheta_{i}+\epsilon_{i, t} \\
& \Delta D_{i, t}=\beta_{0}+\beta_{1} \Delta D_{i, t-1}+\beta_{2} \Delta F_{t} T+\beta_{3} \Delta F_{t}(1-T)+\Phi^{\prime} X+\mu_{t}+\vartheta_{i}+\epsilon_{i, t}
\end{aligned}
$$

where $B D$ is the ratio of bank debt to total debt, $B$ is the logarithm of the stock of bank debt, $D$ is the logarithm of the stock of total debt, $F$ is the logarithm of the interest rate indicator of monetary policy, $T$ is a binary indicator of tight monetary conditions and correspondingly $(1-$ $T$ ) is a binary indicator of easy monetary conditions, $X$ is a vector of other firm characteristics that can affect a firm's debt structure and levels of total and bank debt themselves. Depending on the regression model, $X$ includes logarithm of inventory $(N)$, and logarithm of gearing $(G)$ which is measured by the debt-to-asset ratio. Finally, $\mu$ and $\vartheta$ are time and firm fixed effects, respectively, and $\epsilon$ is the iid error term.

Given the dynamic nature of the equations, these equations have to be estimated using variation of the GMM approach proposed by Arellano and Bover (1995) and Blundell and Bond (1998). As we discuss later, we estimate these models for different ownership categories, firm sizes and firm age.

\section{Context, data and summary statistics}

\subsection{Context of analysis}

The modern history of Indian banking arguably starts in 1969, when the Government of India nationalised the banks, in part as a response to a spate of bank failures, and in part to usher in an era of social banking that could facilitate economic development. The banks operated within an environment of financial repression characterised by administered interest rates, mandatory loan syndication, and pre-emption of their deposit base by the government in the form of 
measures such as high statutory liquidity ratio (SLR) that required banks to invest a significant proportion of their resources in government and quasi-government bonds (Sen and Vaidya, 1998). At the same time, the thrust on social banking led to a large scale expansion of the banking network in India, with the nationalised banks adding over 55,000 branches between 1969 and 1990.

However, while the social agenda of the bank may have been a success, the Indian banking sector in the early 1990s was in distress. While the gross operating profit of scheduled commercial banks rose from 0.8 percent (of assets) in the 1970 s to about 1.5 percent in the 1990s, the net profit of the banks had declined sharply. There was also serious concern about accumulation of non-performing assets, especially among the state-owned banks that accounted for about 88 percent of the assets of the banking sector. Further, the pro-market reforms initiated by the government in 1991 were incompatible with the financial repression that characterised the banking sector. Hence, the Reserve Bank of India (RBI) initiated banking sector reforms in 1992, based on the recommendations of Narasimham Committee I.

The reforms had three main pillars (Sarkar, Sarkar and Bhaumik, 1998; Bhaumik and Dimova, 2004; Bhaumik and Piesse, 2008). First, the banking sector was subjected to greater competition. Incumbent private and foreign owned banks were allowed to expand their branching network and new banks were permitted to enter the market. Second, banks were granted much greater autonomy over disbursal of credit and the pricing of credit. The cash reserve ratio (CRR) and the SLR were reduced sharply between 1992 and 1997, from 15 percent to 10 percent, and from 38.5 percent to 25 percent, respectively. By 1993, the loan threshold above which syndication was mandatory was raised from INR 50 million to INR 500 million, and by 1997 most quantitative restrictions related to mandatory syndication and disbursal of term loans were removed. By 1998, banks were free to determine the lending rates of all loans, with the understanding that lending rates of loans of up to INR 200,000 would not 
exceed the declared prime lending rate (PLR) of banks. Finally, banks were subjected to prudential regulations that were modelled on the recommendations of the Basle committee. Specifically, banks were required to maintain appropriate levels of risk-weighted capital, recognise bad loans early, in accordance with the norms laid down by the RBI, and write off non-performing assets (NPAs).

In 1998, the RBI initiated the second generation of banking reforms, in keeping with the recommendations of Narasimham Committee II. The most important recommendation of the Committee was the creation of asset reconstruction companies (ARCs) to simultaneously improve the quality of the balance sheets of the banks and to facilitate recovery of loans. In a separate development, after a prolonged period of legal disputes, debt recovery tribunals (DRTs) began functioning in India, in earnest, by1999. In other words, the RBI was attempting to simultaneously strengthen the balance sheets of the banks and to put in place institutions that would add to the capability of banks to implement the debt contracts that lie at the very heart of the process of financial intermediation and delegated monitoring.

In many different ways, the reforms were having the expected impact on the Indian banking sector. The Indian banking sector witnessed the entry of new private banks such as Axis Bank and expansion of the branch network of both private and foreign banks. As a consequence, there was noticeable decline in the market share of state-owned banks over time and unsurprisingly this was accompanied by greater competition (Zhao, Casu and Ferrari, 2010). The, in turn, led to technological progress driven productivity growth in the Indian banking sector, albeit at a greater rate for foreign banks than for their domestic counterparts (Casu, Ferrari and Zhao, 2013). Reforms related to DRTs, which has implications for contract enforcement in the credit market, also had the desired impact on loan repayment likelihood (Visaria, 2009). 
However, the evidence about credit allocation is less encouraging. Bhaumik and Piesse (2008) found that in large measure bank-level credit disbursal in India is explained by past allocation of credit. This is consistent with contract level evidence, albeit from a single large state-owned bank, that suggests that loans are made on the basis of past loan sizes rather than on the basis of potential (Banerjee, Cole and Duflo, 2004). In part, this conservativeness can be explained by factors such as expected political cost of bad loans, or by low managerial ability to identify good lending opportunities (even though information that have recently come to light about the extent of bad loans in the Indian banking sector suggests that we should discount the former argument significantly $\left.{ }^{1}\right)$. But alternative, and equally plausible, arguments include persistent high information cost, and the risks associated with lending to firms with entrenched management (which has negative implications for governance quality), especially in a context where bankruptcy is costly (Kang and Nayar, 2004). ${ }^{2}$ In such an environment, state-owned firms that have close relationship with the still dominant state-owned banks and organisational forms such as business groups that are optimised to operate efficiently in contexts of missing markets may have an advantage over standalone private firms, even though the advantage of the former may have declined over time (Bhaumik, Das and Kumbhakar, 2012). The suitability of the Indian context for our empirical exercise is easy to see.

\subsection{Data}

The firm-level data have been obtained from the Prowess database marketed by CMIE, which is widely used for firm-level analysis in the Indian context (Gopalan, Nanda and Seru, 2007;

${ }^{1}$ See, for example, Bad bank loans undermine India's growth hopes (Financial Times, February 18, 2016). Questions are also being raised about the prudence of lending large sums of money to highly leveraged companies such as Kingfisher Airlines.

${ }^{2}$ A new bankruptcy law was passed by the Indian Parliament in 2016, but its enforcement may take time and its efficiency is as yet untested. See, for example, What India's new bankruptcy law means (The Wall Street Journal, May 12, 2016). 
Bhaumik and Selarka, 2012). The database includes data reported in financial statements, including detailed breakdown of sources of bank and non-bank credit. It also includes information about firm characteristics such as inventory and gearing, i.e., the variables included in equations (1) - (3), and ownership information such as business group affiliation and state ownership. It also provides information on industry affiliation of firms.

Further, the data are available for a fairly long time series, thereby facilitating panel analysis. We focus, in particular, on the 2001-08 period. The major reforms initiatives in the Indian banking context were initiated by the turn of the century, by way of easing entry barriers to the sector, greater autonomy to the state-owned banks, liberalisation of interest rates, introduction of prudential norms, and use of debt recovery tribunals (Sarkar, Sarkar and Bhaumik, 1998; Bhaumik and Dimova, 2004; Bhaumik and Piesse, 2008; Visaria, 2009). Hence, the impact of reforms on the credit market should have become apparent by 2001. At the other end of the time line, 2008 is a watershed year for the global financial system beyond which it is difficult to distinguish between the impact of pervasive uncertainty and weak recovery of the global economy from the factors discussed in the previous section.

After accounting for missing information in the firm level data, we are left with an unbalanced panel of 1347 business group affiliated firms, 3273 unaffiliated private firms, 178 state-owned firms (including a handful of joint ventures between state-owned firms and private firms), and 238 foreign firms. Over the sample period, they account for 5121, 10282, 618 and 843 firm-years, respectively. The rationale for combining JVs involving state-owned firms is that in emerging market economies with large state-owned banking sectors partnership with the government should provide privileged access to credit, close to or at par with state-owned firms. 
This information is merged with that about interest rate changes and easy and tight money regimes in India obtained from Bhaumik, Dang and Kutan (2011), to give us the complete set of variables that needed to estimate equations (1) - (3).

\subsection{Summary statistics}

Summary statistics on credit and capital market access of the firms are reported in Table 1 . The information reported in the table suggest the following:

a. India has a bank based financial system, with banks accounting for roughly half the credit obtained by business group affiliated firms, unaffiliated firms and foreign firms. Indeed, only about 9-13 percent of business group affiliated firms, state-owned firms and foreign firms, and only about 3 percent of unaffiliated firms have access to capital/bond markets. This is consistent with the evidence that highlights the persistence of the underdeveloped status of the Indian corporate bond market (Bose and Coondoo, 2003; Khanna and Varottil, 2012).

b. There is a fairly significant market for inter-corporate lending. Indeed, firms of all ownership types borrow (nearly) as much from subsidiaries and corporate bodies, in percentage terms, as from non-bank financial institutions. For example, even unaffiliated private firms that are not part of business group internal capital markets borrow 8.71 percent from subsidiaries and corporate bodies, and 9.09 percent from nonbank financial institutions.

c. Contrary to popular wisdom, state-owned firms do not obtain the majority of their credit from the (largely state-owned) banking system. Bank credit accounts for only 31.53 percent of the credit that they obtain. Much of their credit is obtained directly from the government (25.99 percent) or from subsidiaries and corporate bodies (18.44 percent) that cannot be identified from the data but that are likely to be other state-owned firms. 
d. While state-owned firms and foreign firms are able to obtain unsecured credit relatively easily - nearly half or more of the credit obtained by these firms is unsecured, collateralized credit accounts for about 70 percent of the credit obtained by the vast majority of the firms, whether business group affiliated or unaffiliated. Bank credit accounts for 71-93 percent of this collaterised debt. Since collateral is meant to be a signal to overcome adverse selection problems (Bester, 1985, 1987), this suggests that the Indian credit market is characterised by significant adverse selection, or because of opacity of firms with concentrated ownership and organisational structures such as business groups (Claessens and Fan, 2002; Bhaumik and Dimova, 2014). ${ }^{3}$

e. Finally, despite progressive liberalisation/convertibility of the capital account of balance of payments, a very small proportion of the firms access overseas credit and capital markets. Indeed, even for foreign firms, which have nearly double the proportion of foreign currency debt compared to their nearest domestic competitors ( 8.33 percent vs. 4.29 percent), the business group affiliated firms, foreign current debt account less than a tenth of total debt.

The summary statistics have implications for our empirical analysis. The strong prima facie evidence for adverse selection in the Indian credit market suggests that monetary policy may have a significant impact on disbursal of bank credit, especially during periods of tight monetary regimes. Given that state-owned banks evidently have a safety net in the form of government borrowing, and given that the inter-corporate credit market is much more reliable

\footnotetext{
${ }^{3}$ The weak bankruptcy regime that makes liquidation of borrowers' assets costly in the event of a default possibly matters as well; see Kang and Nayar (2004) for a discussion of India's bankruptcy regime. However, the bankruptcy regime possibly matters less than the adverse selection problem posed by informational asymmetry (Haselmann, Pistor and Vig, 2010). Further, the introduction of debt recovery tribunals, which evidently had a positive impact on credit disbursal by banks (Visaria, 2009), partly ameliorated the problems associated with the costly bankruptcy regime, while problems associated with informational asymmetry and firm opacity were more likely to have persisted.
} 
for business group affiliated firms than for unaffiliated firms, the aforementioned impact of monetary policy is likely to be greater for unaffiliated firms than for their business group affiliated and state-owned domestic competitors. However, while the numbers reported in Table 1 have implications for bank credit, they do not tell us much about overall corporate debt, nor about the proportion of bank credit in total debt, which remains an open empirical question.

\section{Regression results}

The regression results are reported in Tables 2-5. In Tables 2, 3 and 4, we report the estimates for equations (1), (2) and (3). In each of these tables, we report the estimates separately for the four different ownership types in our sample. In Table 5, we explore further the impact of monetary policy on unaffiliated firms that are most likely to be affected by such policy. Specifically, we compare the relative impact on large (those bigger than median) and small (those smaller than median) firms, and older (pre-1990) and younger (post-1990) firms. Finally, for each table and the regression models therein, we report the test statistics for the null hypotheses involving $\mathrm{AR}(2)$ and the appropriateness of the GMM instruments (Hansen statistic). The null hypothesis regarding $\operatorname{AR}(2)$ is rejected only for foreign firms in Table 2, and the null hypothesis for the Hansen statistic is not rejected at the 5 percent level for any of the regression models in any of the tables. This gives us confidence about the validity of our instruments and hence about the regression estimates reported in the tables.

Let is first focus on the impact of monetary policy, and focus on the domestic firms which are much more reliant on the domestic credit market than the foreign firms. In Table 2, in an easy money regime, monetary policy and the associated change in interest rate does not affect change in bank credit, change in total debt and the proportion of bank credit in total debt for any of the firms. This is consistent with the results in Bhaumik, Dang and Kutan (2011) which suggest that over the same period bank lending in India was, by and large, unaffected 
by monetary policy, in an easy money regime. Monetary policy does have an impact on change in bank credit and total debt during a tight money regime - a rise in interest rates leads to a reduction in both bank credit (Table 3) and total debt (Table 4), proportion of bank credit in total debt is unaffected (Table 2) - but only for the unaffiliated private firms. As discussed in the summary statistics section, this is perhaps to be expected. It also suggests that despite the decline in the efficiency of business group structures in reducing financial constraints since the turn of the century (Bhaumik, Das and Kumbhakar, 2012), mechanisms such as internal capital markets (more broadly, inter-corporate networks in credit markets) were still relevant in the Indian context.

In Table 5, we focus on the unaffiliated private firms that are seem to be most vulnerable to monetary policy initiatives during tight money regimes, with attendant implications for their access to bank (and non-bank) credit relative to their business group affiliated and state-owned domestic counterparts. Specifically, we focus on age and size which, following Berger and Udell (1998, 2006), are reasonable proxies for information cost associated with firms. The results suggest that during tight money regimes, smaller firms (coefficient of -23.71) are much more affected by monetary policy than large firms (coefficient of -17.42). This is consistent with the popular and policy concern about smaller firms finding it more difficult to access bank credit than larger firms. However, there is no significant difference in the impact of monetary policy on changes in bank credit of pre-1990 and post-1990 firms (coefficients of -12.32 vs $13.38){ }^{4}$

\footnotetext{
${ }^{4}$ This is apparently at odds with Banerjee, Cole and Duflo's (2004) finding that there is persistent in bank lending, such that newer firms with greater growth opportunities may find it difficult to obtain bank credit, while incumbent firms that do not have as many opportunities to grow may continue to have access to bank credit. Note, however, that Banerjee et al.'s (2004) empirical analysis is limited by virtue of its use of a single bank's data. Further, given that the firms listed in the Prowess database are generally larger and stock exchange listed, they do not necessarily capture the experiences of small and medium enterprises (SMEs) that are included in data obtained from banks.
} 
The coefficient estimates for the other variables have the expected signs. In Tables 2 and 3, an increase in inventory holdings are associated with an increase in bank debt and bank loans for business group affiliated and unaffiliated private firms but not for state-owned and foreign firms, while in Table 4, we observe that higher inventories raise total debt for all firms except foreign firms. In Tables 3 and 4, bank debt last period has no predictive power for bank loans or total debt. Regarding lagged dependent variables, we see significant persistency in bank debt ratio in Table 2, while no persistency in Table 4 for the volume of bank debt. Interestingly, in Table 3 we observe significant persistency only for the state-owned firms and higher bank loans last period are associated with a decline in the loans this period,

\section{Conclusion and policy implications}

Given the correlation (even causality) between banking sector development and economic growth, it is not surprising that many emerging market economies are advised to undertake suitable banking sector reforms, and indeed many of them such as India have ushered in a wide set of reforms over a long period of time. However, while there is a large literature on the impact of these reforms on performance of banks, often distinguishing between banks of different ownership, there is considerably less understanding of the impact of these reforms on the process of financial intermediation. In this paper, we argue that if banking sector reforms remove frictions in the credit market, this should be reflected in the bank channel of transmission of monetary policy. In particular, monetary policy should not affect firms of different ownership types - some of which are optimised for markets with frictions while others are not - differently, nor should it have significantly different effects on firms at different points of age and size distributions. We examine these propositions in the Indian context which is characterised by both significant banking sector reforms and existence of different types of firms, some of which have advantages over others with respect to mitigating credit market 
frictions. Our empirical results suggest, in an easy money regime, monetary policy and the associated change in interest rate does not affect change in bank credit, change in total debt and the proportion of bank credit in total debt for any of the firms. This is consistent with extant literature on the bank channel transmission of monetary policy in India (Bhaumik, Dang and Kutan, 2011). However, in a tight policy regime, unaffiliated private firms have the most vulnerable to monetary policy stand where other types of firms are relatively less affected by changes in monetary policy. We also find that during tight monetary policy regimes, smaller firms are much more affected by monetary policy than large firms.

Our empirical results have two important policy implications. First, there seems a bank channel for monetary policy at work, suggesting some success of banking sector reforms in India. In other words, greater competition, greater autonomy with respect to loan disbursal and pricing of loans, subjecting banks to prudential norms, and establishing mechanisms for contract enforcement are all reforms worth exploring in emerging market contexts. Second, banking sector reforms alone are clearly not sufficient to mitigate credit market frictions that give some kinds of firms (such as those affiliated to business groups or the state) an advantage over others, an advantage that can lead to misallocation of credit. To overcome the residual frictions, governments may have to supplement banking sector reforms with wider reforms with respect to bankruptcy laws and corporate governance, thereby eschewing the silo-based approach to banking sector reforms.

Regarding further research, it would be interesting to see whether introduction of these complementary changes to bankruptcy law etc have the expected or desired impact on emerging market banking sectors. Events such as the introduction of the new bankruptcy law in India can be used as natural experiments for such empirical investigations. 


\section{References}

Abiad, A., Detragiache, E., Tressel, T. (2010). A new database of financial reforms. IMF Staff Papers, 57(2): 281-302.

A ̆gca, Ş., Celasun, O. (2012). Banking sector reforms and corporate borrowing costs in emerging markets. Emerging Markets Finance and Trade, 48(4): 71-95.

Akyuz, Y. (1990). Financial system and policies in Turkey in the 1980s. In: Arincali, T., Rodrik, D. (eds.) The Political Economy of Turkey, Palgrave Macmillan, pp. 98-131.

Amsden, A.H., Euh, Y-D. (1993). South Korea's 1980s financial reforms: Good-bye financial repression (maybe), hello new institutional restraints. World Development, 21(3): 379-390.

Arellano, M., Bover, O. (1995). Another look at the instrumental variable estimation of errorcomponents models, Journal of Econometrics, 68(1): 29-51.

Arestis, P., Demetriades, P.O. (1997). Financial development and economic growth: Assessing the evidence. Economic Journal, 107(442): 783-799.

Banerjee, A., Cole, S., Duflo, E. (2004). Bank Financing in India, In: Panagrariya, A., Bosworth, B. and Berry, S. (Eds.) India Policy Forum, Volume 1, Brookings Institutions, pp. 277-232.

Berger, A.N., Udell, G. (1998). The economics of small business finance: The roles of private equity and debt markets in the financial growth cycle, Journal of Banking and Finance, 22(6): 613-673.

Berger, A.N., Udell, G. (2006). A more complete conceptual framework for SME finance, Journal of Banking and Finance, 30(11): 2945-2966.

Bernanke, B.S., Gertler, M. (1995). Inside the black box: The credit channel of monetary policy transmission, Working paper no. 5146, National Bureau of Economic Research, Cambridge, MA. 
Bester, H. (1985). Screening vs rationing in credit markets with imperfect competition, American Economic Review, 75(4): 850-855.

Bester, H. (1987). The role of collateral in credit markets with imperfect competition, European Economic Review, 31(4): 887-899.

Bhaumik, S.K., Dang, V., Kutan, A. (2011). Implications of bank ownership for the credit channel of monetary policy transmission: Evidence from India, Journal of Banking and Finance, 35(9): 2418-2426.

Bhaumik, S.K., Das, P.K., Kumbhakar, S.C. (2012). A stochastic frontier approach to modelling financial constraints in firms: An application to India, Journal of Banking and Finance, 36(5): 1311-1319.

Bhaumik, S.K., Dimova, R. (2004). How important is ownership in a market with a level playing field? The Indian banking sector revisited, Journal of Comparative Economics, 32(1): 165-180.

Bhaumik, S.K., Dimova, R. (2014). How Family Firms Differ: Structure, Strategy, Governance and Performance, Palgrave.

Bhaumik, S.K., Piesse, J. (2008). Does lending behaviour of banks in emerging economies vary by ownership? Evidence from the Indian banking sector? Economic Systems, 32(2): 177196.

Bhaumik, S.K., Selarka, E. (2012). Does ownership concentration improve M\&A outcomes in emerging markets? Evidence from India, Journal of Corporate Finance, 18(4): 717-726.

Blundell, R., Bond, S. (1998). Initial conditions and moment restrictions in dynamic panel data models, Journal of Econometrics, 87(1): 115-143.

Bose, S., Coondoo, D. (2003). A study of the Indian corporate debt market, ICRA's Bulletin Money \& Finance, 2(12): 2(12): 25-51. Downloadable from http://ssrn.com/abstract=421440. 
Burget, J.D., Warnock, F.E., Warnock, V.C. (2015). Bond market development in developing Asia. Working paper no. 448, ADB Economics Working Paper Series, Downloadable from http://www.adb.org/sites/default/files/publication/173190/ewp-448.pdf.

Casu, B., Ferrari, A., Zhao, T. (2013). Regulatory reform and productivity change in Indian banking, Review of Economics and Statistics, 95(3): 1066-1077.

Claessens, S., Fan, J.P. (2002). Corporate governance in Asia: A survey. International Review of Finance, 3(2), 71-103.

Cojocaru, L., Falaris, E. M., Hoffman, S.D., Miller, J.F. (2016). Financial System Development and Economic Growth in Transition Economies: New Empirical Evidence from the CEE and CIS Countries. Emerging Markets Finance and Trade, 52:1, 223-236.

Demetriades, P.O., Hussein, K.A. (1996). Does financial development cause economic growth? Time-series evidence from 16 countries. Journal of Development Economics, 51(2): $387-411$.

Fisman, R., Wang, Y. (2010). Trading favors with Chinese business groups. American Economic Review Papers and Proceedings, 100(2): 429-433.

Fry, M.J. (1997). In favour of financial liberalisation. Economic Journal, 107(442): 754-770. Haselmann, R., Pistor, K., Vig, V. (2010). How laws affect lending, Review of Financial Studies, 23 (2):549-580.

Huang, Z. (2003). Evidence of a bank lending channel in the UK, Journal of Banking and Finance, 27(3): 491-510.

Kang, N., Nayar, N. (2004). The evolution of corporate bankruptcy law in India, ICRA's Bulletin Money \& Finance, 37-57.

Khanna, T., Palepu, K. (2000). Is group affiliation profitable in emerging markets? An analysis of diversified Indian business groups, Journal of Finance, 55 (2), 867-891. 
Khanna, V.S., Varottil, U. (2012). Developing the market for corporate bonds in India, Mimeo, University of Michigan Law School, Downloadable from http://ssrn.com/abstract=2021602. Khwaja, A.I., Mian, A. (2005). Do lenders favor poltically connected firms? Rent provision in an emerging financial market. Quarterly Journal of Economics, 120(4): 1371-1411.

King, R.G., Levine, R. (1993). Finance and growth: Schumpeter may be right. Quarterly Journal of Economics, 108(3): 717-737.

Lagoarde-Segot, T. (2009). Financial reforms and time-varying microstructures in emerging equity markets. Journal of Banking and Finance, 33(10): 1755-1769.

Lardy, N. (2008). Financial repression in China. Working paper no. PB08-8, Peterson Institute for Institutional Economics, Downloadable from http://ssrn.com/abstract=2126174.

Love, I., Rachinsky, A. (2015). Corporate Governance and Bank Performance in Emerging Markets: Evidence from Russia and Ukraine. Emerging Markets Finance and Trade, 51:sup2, S101-S121.

Oliner, S.D., Rudebusch, G.D. (1996). Is there a broad credit channel for monetary policy? Economic Review, Federal Reserve Board of San Francisco, 1: 3-13.

Osborne-Kinch, J., Holton, S. (2010). A discussion of the monetary condition index, Quarterly Bulletin, Central Bank of Ireland, January: 68-79.

Sarkar, J., Sarkar, S., Bhaumik, S.K. (1998). Does ownership always matter?- Evidence from the Indian banking industry, Journal of Comparative Economics, 26(2): 262-281.

Sen, K., Vaidya, R. (1998). The Process of Financial Liberalization in India, New Delhi: Oxford University Press.

Tendulkar, R. (2015). Corporate bond markets: An emerging markets perspective, Vol. II, Staff working paper no. SWP6/2016, OICU-IOSCO, Downloadable from https://www.iosco.org/library/pubdocs/pdf/IOSCOPD510.pdf. 
Tsai, W., Wang, W., Ho, P., Lin, C. (2016). Bank loan supply in the financial crisis: Evidence from the role of political connection, Emerging Markets Finance and Trade, 52(2):487-497. Visaria, S. (2009). Legal reform and loan repayment: The microeconomic impact of debt recovery tribunals in India, American Economic Journal: Applied Economics, 1(3): 59-81. Zhang, M., Su, J., Sun, Y., Zhang, W., Shen, N. (2015). Political connections and corporate diversification: An exploration of Chinese firms, Emerging Markets Finance and Trade, 51(1): 234-246.

Zhao, T., Casu, B., Ferrari, A. (2010). The impact of regulatory reforms on cost structure, ownership and competition in Indian banking, Journal of Banking and Finance, 34(1): 246254. 
Table 1

Sources of credit

\begin{tabular}{|c|c|c|c|c|}
\hline & $\begin{array}{c}\text { Business group } \\
\text { affiliated }\end{array}$ & $\begin{array}{c}\text { Unaffiliated } \\
\text { private firms }\end{array}$ & $\begin{array}{l}\text { State-owned firms } \\
\text { (including JVs) }\end{array}$ & Foreign firms \\
\hline Proportion borrowed from bank & $50.77 \%$ & $58.07 \%$ & $31.53 \%$ & $48.49 \%$ \\
\hline $\begin{array}{l}\text { Proportion borrowed from financial } \\
\text { institutions }\end{array}$ & $11.39 \%$ & $9.09 \%$ & $5.67 \%$ & $5.44 \%$ \\
\hline $\begin{array}{l}\text { Proportion of borrowing that is } \\
\text { secured }\end{array}$ & $69.67 \%$ & $71.58 \%$ & $43.43 \%$ & $53.19 \%$ \\
\hline $\begin{array}{l}\text { Proportion of secured borrowing that } \\
\text { is from banks }\end{array}$ & $93.72 \%$ & $71.58 \%$ & $91.53 \%$ & $80.64 \%$ \\
\hline $\begin{array}{l}\text { Proportion of borrowing from } \\
\text { subsidiaries and other corporate bodies }\end{array}$ & $12.09 \%$ & $8.71 \%$ & $18.44 \%$ & $12.01 \%$ \\
\hline $\begin{array}{l}\text { Proportion of borrowing from } \\
\text { governments }\end{array}$ & $1.06 \%$ & $0.78 \%$ & $25.99 \%$ & $2.11 \%$ \\
\hline Proportion of foreign currency debt & $4.29 \%$ & $2.46 \%$ & $2.73 \%$ & $8.33 \%$ \\
\hline $\begin{array}{l}\text { Proportion of firms with access to } \\
\text { capital markets }\end{array}$ & $13.59 \%$ & $2.96 \%$ & $9.30 \%$ & $9.43 \%$ \\
\hline
\end{tabular}


Table 2

Impact of monetary policy on debt structure

Dependent variable: Ratio of bank debt to total debt, (B/D)t

\begin{tabular}{|l|l|l|l|l|}
\hline & $\begin{array}{c}\text { Business group } \\
\text { affiliated }\end{array}$ & $\begin{array}{c}\text { Unaffiliated } \\
\text { private firms }\end{array}$ & $\begin{array}{c}\text { State-owned } \\
\text { firms (including } \\
\text { JV) }\end{array}$ & Foreign firms \\
\hline$(\mathrm{B} / \mathrm{D})_{\mathrm{t}-1}$ & $0.97 * * *$ & $0.98 * * *$ & $1.05 * * *$ & $1.01 * * *$ \\
& $(0.03)$ & $(0.02)$ & $(0.07)$ & $(0.08)$ \\
\hline$\Delta \mathrm{N}_{\mathrm{t}}$ & $0.03 * * *$ & $0.02 * * *$ & 0.004 & -0.007 \\
& $(0.01)$ & $(0.007)$ & $(0.03)$ & $(0.04)$ \\
\hline$\Delta \mathrm{G}_{\mathrm{t}}$ & $0.04 * *$ & $0.04 * * *$ & 0.003 & 0.04 \\
& $(0.02)$ & $(0.01)$ & $(0.03)$ & $(0.03)$ \\
\hline$\Delta \mathrm{F}_{\mathrm{t}} \times$ & -1.63 & -1.25 & 0.57 & 0.92 \\
Easy money & $(0.99)$ & $(0.79)$ & $(1.41)$ & $(2.12)$ \\
\hline$\Delta \mathrm{F}_{\mathrm{t}} \times$ & -0.03 & -0.39 & 0.11 & 0.34 \\
Tight money & $(0.73)$ & $(0.45)$ & $(0.47)$ & $(1.90)$ \\
\hline & & & & \\
\hline AR(2) & 0.60 & 0.96 & 0.65 & $1.95 *$ \\
$($ Prob $>$ z) & $(0.54)$ & $(0.33)$ & $(0.51)$ & $(0.052)$ \\
\hline Hansen statistic & 22.97 & 23.04 & 16.59 & 17.22 \\
$($ Prob $>$ chi-sq) & $(0.23)$ & $(0.23)$ & $(0.61)$ & $(0.57)$ \\
\hline Number of firms & 1347 & 3273 & 178 & 238 \\
\hline Number of obs. & 5121 & 10282 & 618 & 843 \\
\hline
\end{tabular}


Table 3

Impact of monetary policy on volume of bank loans

Dependent variable: Change in volume of bank loans, $\Delta \mathrm{B}_{\mathrm{t}}$

\begin{tabular}{|l|l|l|l|l|}
\hline & $\begin{array}{c}\text { Business group } \\
\text { affiliated }\end{array}$ & $\begin{array}{c}\text { Unaffiliated } \\
\text { private firms }\end{array}$ & $\begin{array}{c}\text { State-owned } \\
\text { firms (including } \\
\text { JV) }\end{array}$ & Foreign firms \\
\hline$\Delta \mathrm{B}_{\mathrm{t}-1}$ & 0.10 & -0.19 & $-0.61 * * *$ & -0.44 \\
& $(0.20)$ & $(0.18)$ & $0.16)$ & $(0.48)$ \\
\hline$\Delta \mathrm{N}_{\mathrm{t}}$ & $0.35 * * *$ & $0.24 * * *$ & -0.47 & 0.18 \\
& $(0.09)$ & $(0.03)$ & $(0.35)$ & $(0.45)$ \\
\hline $\mathrm{BD}_{\mathrm{t}-1}$ & 0.17 & 0.19 & -0.46 & -0.36 \\
& $(0.19)$ & $(0.13)$ & $(0.49)$ & $(0.56)$ \\
\hline$\Delta \mathrm{F}_{\mathrm{t}} \times$ & 2.29 & -1.39 & -9.81 & -1.02 \\
Easy money & $(4.51)$ & $(3.77)$ & $(9.21)$ & $(13.14)$ \\
\hline$\Delta \mathrm{F}_{\mathrm{t}} \times$ & $-10.66 *$ & $-19.21 * * *$ & -13.92 & 23.59 \\
Tight money & $(5.89)$ & $(4.49)$ & $(15.52)$ & $(29.58)$ \\
\hline & & & & \\
\hline $\mathrm{AR}(2)$ & 0.84 & -0.14 & -2.01 & 0.09 \\
$($ Prob $>$ z) & $(0.40)$ & $(0.89)$ & $(0.04)$ & $(0.92)$ \\
\hline Hansen statistic & 12.94 & 7.93 & 7.93 & 5.10 \\
$($ Prob $>$ chi-sq) & $(0.07)$ & $(0.34)$ & $(0.34)$ & $(0.65)$ \\
\hline Number of firms & 1060 & 2247 & 118 & 161 \\
\hline Number of obs. & 3314 & 6073 & 337 & 419 \\
\hline
\end{tabular}


Table 4

Impact of monetary policy on volume of total debt

Dependent variable: Change in volume of total debt, $\Delta \mathrm{D}_{\mathrm{t}}$

\begin{tabular}{|l|l|l|l|l|}
\hline & $\begin{array}{c}\text { Business group } \\
\text { affiliated }\end{array}$ & $\begin{array}{c}\text { Unaffiliated } \\
\text { private firms }\end{array}$ & $\begin{array}{c}\text { State-owned } \\
\text { firms (including } \\
\text { JV) }\end{array}$ & Foreign firms \\
\hline$\Delta \mathrm{D}_{\mathrm{t}-1}$ & -0.11 & -0.05 & -0.10 & -0.84 \\
& $(0.15)$ & $(0.20)$ & $0.37)$ & $(0.56)$ \\
\hline$\Delta \mathrm{N}_{\mathrm{t}}$ & $0.20 * * *$ & $0.20 * * *$ & $0.23 * *$ & -0.01 \\
& $(0.06)$ & $(0.03)$ & $(0.11)$ & $(0.23)$ \\
\hline $\mathrm{BD}_{\mathrm{t}-1}$ & 0.24 & 0.09 & -0.04 & -0.15 \\
& $(0.18)$ & $(0.11)$ & $(0.31)$ & $(0.59)$ \\
\hline$\Delta \mathrm{F}_{\mathrm{t}} \times$ & 4.33 & -2.49 & 0.82 & 2.84 \\
Easy money & $(3.85)$ & $(2.84)$ & $(4.64)$ & $(11.60)$ \\
\hline$\Delta \mathrm{F}_{\mathrm{t}} \times$ & -6.65 & $-16.64 * * *$ & -0.66 & 11.91 \\
Tight money & $(11.26)$ & $(4.14)$ & $(5.11)$ & $(19.18)$ \\
\hline & & & & \\
\hline AR(2) & -0.70 & 0.38 & 1.22 & -0.70 \\
$($ Prob $>$ z) & $(0.48)$ & $(0.71)$ & $(0.22)$ & $(0.48)$ \\
\hline Hansen statistic & 3.53 & 4.20 & 5.10 & 1.21 \\
(Prob $>$ chi-sq) & $(0.83)$ & $(0.75)$ & $(0.65)$ & $(0.87)$ \\
\hline Number of firms & 1176 & 2494 & 147 & 202 \\
\hline Number of obs. & 3713 & 6832 & 433 & 596 \\
\hline
\end{tabular}


Table 5

Impact of monetary policy on volume of bank loans - unaffiliated private companies

Dependent variable: Change in volume of bank loans, $\Delta \mathrm{B}_{\mathrm{t}}$

\begin{tabular}{|l|l|l|l|l|}
\hline & \multicolumn{2}{|c|}{ Differentiated by size } & \multicolumn{2}{c|}{ Differentiated by age } \\
\hline & Large firms & Small firms & Pre-1990 firms & Post-1990 firms \\
\hline$\Delta \mathrm{B}_{\mathrm{t}-1}$ & -0.07 & -0.49 & -0.02 & -0.30 \\
& $(0.14)$ & $(0.41)$ & $(0.22)$ & $(0.25)$ \\
\hline$\Delta \mathrm{N}_{\mathrm{t}}$ & $0.24 * * *$ & $0.25 * * *$ & $0.27 * * *$ & $0.24 * * *$ \\
& $(0.04)$ & $(0.06)$ & $(0.04)$ & $(0.05)$ \\
\hline $\mathrm{BD}_{\mathrm{t}-1}$ & 0.16 & 0.32 & $0.25 *$ & 0.19 \\
& $(0.12)$ & $(0.36)$ & $(0.15)$ & $(0.20)$ \\
\hline$\Delta \mathrm{F}_{\mathrm{t}} \times$ & -3.25 & 6.46 & 3.13 & -4.22 \\
Easy money & $(3.63)$ & $(12.12)$ & $(3.95)$ & $(6.04)$ \\
\hline$\Delta \mathrm{F}_{\mathrm{t}} \times$ & $-17.42 * * *$ & $-23.71 * * *$ & $-12.32 * * *$ & $-13.38 * *$ \\
Tight money & $(4.72)$ & $(8.37)$ & $(3.69)$ & $(6.67)$ \\
\hline & & & & \\
\hline $\mathrm{AR}(2)$ & 0.30 & -0.86 & 0.37 & -0.60 \\
$($ Prob $>$ z) & $(0.764)$ & $(0.38)$ & $(0.71)$ & $(0.55)$ \\
\hline Hansen statistic & 7.61 & 14.06 & 8.73 & 7.37 \\
(Prob $>$ chi-sq) & $(0.37)$ & $(0.05)$ & $(0.27)$ & $(0.39)$ \\
\hline Number of firms & 1403 & 844 & 1467 & 780 \\
\hline Number of obs. & 4109 & 1964 & 4118 & 1955 \\
\hline
\end{tabular}

